\title{
Alterations in membrane function, organization and composition in the obese ob/ob mouse
}

By David A. York, Department of Nutrition, School of Biochemical and Physiological Sciences, Southampton University, Bassett Crescent East, Southampton $\mathrm{SO}_{9} \mathrm{TU}$

In recent years, in vitro investigations with model membrane systems have been used to show the influence of membrane composition or fluidity, or both, on the activity of membrane-associated proteins. These studies have been supported by investigations on native membranes in which the lipid fluid environment has been perturbed or into which differing lipids have been equilibrated (for reviews, see Sanderman, 1978; Houslay \& Gordon, 1983; Stubbs \& Smith, 1984). While such artificial systems clearly illustrate the interdependence of lipid composition to membrane protein function, the demonstration that dietary manipulation may also alter membrane composition and influence the activity of membrane-associated proteins (Innis \& Clandinin, 1981; McMurdine et al. 1983; Wahle, 1983) suggests that such interrelations are of physiological significance to the cell and animal. Membrane phospholipids also serve the role of eicosanoid precursors and changes in the relative amounts of individual polyunsaturated fatty acids may influence membrane function through the production of prostaglandins, thromboxane and leukotrienes. Obesity entails the deposition of excess lipid, particularly triacylglycerols and cholesterol, within cells and is often reported to be associated with a change in fatty acid composition (Bray \& York, 1979). In the light of the ability to influence membrane composition by diet, it would be surprising if the presence of abnormal quantities of lipid within cells did not influence the composition and function of membranes. In the present paper, I would like to review studies of membrane function in obesity, with particular regard to the function of integral membrane proteins. The review will concentrate on the genetically-obese $o b / o b$ mouse, since it is on this animal model of obesity that the majority of research has been conducted.

\section{Membrane function in the ob/ob mouse}

Table $\mathrm{x}$ lists a number of membrane-associated processes which have been reported to be abnormal in the $o b / o b$ mouse. The diversity of these abnormalities in the function of membrane-localized proteins is evident from Table I, but our knowledge of the causes of these changes is, for most of the examples, rather superficial. Impaired basal glucose uptake into muscle of $o b / o b$ mice has been shown using both isolated soleus muscle (Cuendot et al. 1976; Le Marchand-Brustel el al. 1978) and perfused hind-limb preparations (Oshima et al. 1984). This impairment does not appear to be related to the developing insulin insensitivity of the muscle, which is clearly demonstrable by the poor response of 
Table $\mathrm{I}$. Some alterations in membrane function in obese mice

I. Transport and secretion:

Glucose transport

Calcium transport

Sodium-potassium transport

Insulin secretion

2. Receptors

Adrenergic

Insulin

Vasopressin

Glucagon

Angiotensin II

32 kdalton protein of brown adipose tissue mitochondria

Lectin binding

3. Enzymes

Adenylate cyclase ( $E C$ 4.6.1.1)

5 '-Nucleotidase (EC 3.1.3.5)

$\left[\mathrm{Na}^{+}+\mathrm{K}^{+}\right]$ATPase $(E C$ 3.6.1.8)

Microsomal NADPH-cyt $\mathrm{P}_{450}$ oxidoreductase $(E C$ 1.6.2.4)

Microsomal ethoxycoumarin-o-ethyl transferase (EC 2.2.1.99)

Mitochondrial oxidative enzymes

4. Other

Immune system, T-cell function
References ${ }^{\bullet}$

Cuendot et al. 1976

Fraser \& Trayhurn, 1984

Flier et al. $198 \mathrm{r}$

Beloff-Chain et al. 1973

Begin-Heick, 1981

Kahn et al. 1973

Assimacopoulos-Jeannet et al. 1984

Hogan \& Himms-Hagen, 1980

Chang et al. 1975

French \& York, 1984

French et al. 1983

Hughes \& York, 1983

Hyslop et al. 1982

Rouer et al. 1980

Katyare \& Howland, 1980

Meade \& Sheena, 1979

-Further references are given in the text.

both glucose transport and metabolism to insulin stimulation. Neither does the reduction in glucose transport result from increased oxidation of free fatty acids and the consequent impairment of glucose metabolism and transport (Cuendot et al. 1976). However, it is of note that both basal glucose transport into hind-limb muscle of $o b / o b$ mice and its responsiveness to insulin were normalized after adrenalectomy (Oshima et al. 1984). Further, basal glucose transport and its coupling to the insulin receptor may be sensitive to its phospholipid environment within the membrane (Czech, 1980).

Abnormalities in calcium transport both at the cellular and subcellular levels have been reported in $o b / o b$ mice. The stimulation of $\mathrm{Ca}$ uptake into adipocytes by a variety of hormones and by cyclic AMP was absent in $o b / o b$ mice (Dehaye et al. 1979). Isolated mitochondria from liver and brown adipose tissue of $o b / o b$ mice showed increased rates of ${ }^{45} \mathrm{Ca}$ uptake and release compared with those of lean mice (Fraser \& Trayhurn, ${ }^{984}$ ), indicative of an activation of the $\mathrm{Ca}^{2+}$ uniporter.

Hyperinsulinaemia is a common characteristic of obesity in both man and animal models (Bray \& York, 1979). There is considerable evidence to suggest that this hyperinsulinaemia may, in some models of obesity at least, be secondary either 


\section{Vol. 44 Nutritional aspects of membrane structure and function I9 I}

to any hyperphagia or to an altered autonomic regulation of the pancreatic $\beta$-cells, parasympathetic stimulation predominating over sympathetic inhibitory influences (Bray \& York, 1979; Jeanrenaud, 1981), or to enhanced stimulation by pituitary $\beta$-cell tropin (Beloff-Chain et al. 1979; Billingham et al. 1982). However, an increased insulin secretory response to a number of stimuli was also evident in isolated islets incubated in vitro when separated from all nervous, endocrine and nutrient influences (Beloff-Chain et al. 1973; Lavine et al. 1977).

The binding of numerous hormones to their plasma membrane receptors is altered in the obese $a b / o b$ mouse. The reduction in the number of insulin receptors on hepatic, adipocyte and muscle plasma membranes has been attributed to a down regulation of the reception number in the presence of a high circulating insulin concentration (Kahn et al. 1973; Soll et al. 1975; Le Marchand-Brustel \& Freychet, 1978; Grundleger et al. 1980). The number of $\beta$-receptors on white adipocytes of $o b / o b$ mice has been shown to be reduced compared with those of lean mice, although the affinity remains normal (Begin-Heick, 198I; French \& York, 1984). However, the $\beta_{2}$-subtype predominates in $o b / o b$ mice rather than the $\beta_{1}$-subtype as in lean mice (Begin-Heick, 1981 ). The absence of any vasopressin regulation of hepatic glycogenolysis or lipogenesis in the $o b / o b$ mouse has recently been attributed to the complete absence of vasopressin $V_{1}$-type receptors in the liver, whereas renal vasopressin $V_{2}$-type receptors are present in normal numbers and have normal affinity (Assimacopoulos-Jeannet et al. 1984). Vasopressin $V_{2}$ receptor effects are mediated through adenylate cyclase ( $E C_{4}$.6.r.1) whereas the $\mathrm{V}_{1}$ receptor effects are mediated through the phosphoinositide regulation of $\mathrm{Ca}$ transport. The numbers of specific receptors for angiotensin II and glucagon are also reduced in hepatocytes of $o b / o b$ mice and result in a reduction in sensitivity and maximal response of phosphorylase phosphatase ( $E C$ 3.1.3.17) to angiotensin II and a reduction in sensitivity only for glucagon (Assimacopoulos-Jeannet et al. 1984). The explanation of these reductions in a specific-binding of vasopressin, glucagon and angiotensin II are, as yet, unclear but do not appear to reflect down regulation in response to elevated levels of circulating hormone.

Membrane fluidity and membrane lipid composition have been shown to affect the specific binding of a variety of hormones to their receptors. Temperature-induced reduction in fluidity and increases in membrane phospholipid acyl unsaturation have been associated with an increase in the number of insulin receptor sites (Gould et al. 1979; Ginsberg et al. 1981). Reconstitution experiments with $\beta$-receptors from turkey erythrocyte membranes suggest that phospholipids, in particular phosphatidylethanolamine, are important in obtaining maximal binding (Kirolovsky \& Schramm, 1983) whereas experiments using phospholipase treatment have suggested that the phospholipid polar head groups might also influence $\beta$-receptor binding, although the interpretation of these latter experiments has been queried (Loh \& Law, 1980).

The specific binding of $\left[{ }^{3} \mathrm{H}\right] \mathrm{GDP}$ to the 32 kdalton protein of brown adipose tissue mitochondria has been used extensively to illustrate the deficiency in the thermogenic proton conductance pathway of obese rodents. However, the apparent 
lack of binding sites and of proton translocation may reflect a 'masking' of the protein and its GDP binding sites in the membrane since the quantity of $\mathbf{3 2}$ kdalton protein within the membrane of both obese $o b / o b$ mice and obese $f a / f a$ rats appears to be normal by both immunoassay (M. Ashwell, S. J. Holt and D. A. York, unpublished results) and gel electrophoretic techniques (Hogan \& Himms-Hagen, 1980). Chang et al. (1975) originally suggested that there was a generalized defect in the production of membrane glycoproteins in $o b / o b$ mice from their studies on lectin binding in which they demonstrated that the magnitude of the reduction in binding of concanavalin $\mathrm{A}$ and wheat-germ agglutinin to hepatic and renal membranes of obese mice was far greater than the reduction in binding of hormones such as insulin where the receptor is known to be a glycoprotein. Although this suggestion has not been extensively investigated, Sena et al. (1982) have shown a gene-dependent reduction in sialic acid residues in the liver and brain of $o b / a b$ mice. This work, however, requires validation since the values were expressed on the basis of dry tissue weight rather than membrane protein. Nevertheless, the distribution of the major ganglioside fractions was not significantly different in $o b / o b$ mice. Perhaps the best illustration of a membrane glycoprotein change in obesity has been reported by Makula \& Goekjian (1982) who demonstrated a reduction in the number of galactose-containing residues and a compensatory increase in non-carbohydrate-containing proteins in adipocyte plasma membranes of obese $f a / f a$ rats. The possible interrelations between any generalized defect in membrane glycoproteins and the impaired function of specific membrane glycoproteins, such as the insulin receptor and glucose transporter, remain to be investigated.

The activities of a number of membrane-associated enzymes are altered in the obese $a b / o b$ mouse (see Bray \& York, 1979). Not only are the activities of the enzymes listed in Table $\mathrm{I}$ altered in $o b / o b$ mice, but the temperatures of inflection in the Arrhenius plots of their activities are also different from those of lean mice (Rouer et al. 1980; Hyslop et al. 1982; French et al. 1983; Hughes \& York, 1983; R. R. French and D. A. York, unpublished results). Arrhenius break temperatures are indicative of phase transitions within the membrane lipid which influence the activity of that enzyme. Changes in the break temperature are thought to be indicative of interactions with an altered lipid environment within the membrane bilayer (Houslay, 1985). Thus it has been suggested that the increase in activity and decrease in activation energy of microsomal NADPH-cytochrome $P_{450}$ oxidoreductase (NADPH-cytochrome reductase; EC 1.6.2.4) results from its interaction with a more unsaturated phosphatidylcholine in the obese mice (Hyslop et al. 1982). Alterations in the phospholipid composition of microsomes may be responsible for the increase in the proportion of glutathione-insulin transhydrogenase (thiol oxidase; $E C$ 1.8.3.2) in the latent form in $o b / o b$ mice (Varandani \& $\mathrm{Nafz}, 1976)$. The reduction in activity of plasma membrane $\left[\mathrm{Na}^{+}+\right.$ $\mathrm{K}^{+}$]ATPase in a number of tissues of $o b / o b$ mice was correlated with a lack of enzyme units within the membrane as indicated by specific binding of the inhibitor $\left[{ }^{3} \mathrm{H}\right.$ ]ouabain (York et al. 1978; Lin et al. 1978, 1979b). However, this now seems 
unlikely since the reduction in $\left[{ }^{3} \mathrm{H}\right.$ ]ouabain binding to synaptosomal membranes of $a b / o b$ mice was abolished after treatment of the membranes with low concentrations of deoxycholate. Furthermore, the Arrhenius break temperatures for both $\left[{ }^{3} \mathrm{H}\right]$ ouabain binding and $\left[\mathrm{Na}^{+}+\mathrm{K}^{+}\right] \mathrm{ATPase}$ activity were reduced in $o b / o b$ mice (Hughes \& York, 1983 ). The findings suggest that the loss of $\left[\mathrm{Na}^{+}+\right.$ $\left.\mathrm{K}^{+}\right] A T P a s e$ enzyme activity may result from the development of an abnormal membrane lipid environment in the obese mouse. Membrane phospholipids are known to affect $\left[\mathrm{Na}^{+}+\mathrm{K}^{+}\right] A T$ Tase activity in a variety of membrane systems (Sanderman, 1978; Jorgensen, 1982).

The impaired isoprenaline stimulation of adenylate cyclase ( $E C$ 4.6.1.r.) in adipocyte plasma membranes of $o b / o b$ mice is associated with a linear rather than bifunctional Arrhenius plot (R. R. French and D. A. York, unpublished results) and was improved after housing the mice at $34^{\circ}$ when membrane fluidity was normalized (Hyslop \& York, 1980). Such findings suggest that the impaired isoprenaline stimulation of adenylate cyclase in $o b / o b$ mice may be associated with changes in membrane fluidity or composition.

Reduced cellular immunity has been demonstrated for both the obese $(a b / o b)$ and the diabetic $(d b / d b)$ mouse, whereas the formation of antibodies by $B$ lymphocytes is normal or even enhanced (for reviews see Bray \& York, 1979; Meade \& Sheena, 1979). In vitro experiments have shown that this impairment in T-cell function in the obese and diabetic mice results from the environment in which it resides rather than from a defect in the T-cell function per se. The basis of the inhibitory influences in T-cell function in these obese models is not known. However, once again it is known that diet, in particular its lipid composition, may influence $\mathrm{T}$-cell function possibly through changes in membrane composition (Vitale \& Broitman, $198 \mathrm{r}$; Smith et al. 1985).

The obesity of the obese $a b / o b$ mouse is inherited as a single gene (homozygous recessive trait). It is unlikely that the wide diversity of membrane functional changes could be explained as a pleiotropic expression of this single gene. Since many of the membrane protein functions described in Table I are known to be responsive to membrane lipid composition, the possibility that widespread changes in membrane lipid composition may be associated with the obese state and be responsible for some of the membrane functional changes has been investigated.

\section{Fluorescence polarization studies of membranes from obese mice}

The fluorescence polarization technique (see Lee, 1985) using a diphenylhexatriene (DPH) probe has been used to compare membrane fluidity in lean and obese $o b / o b$ mice. An increase in fluidity (decrease in polarization) is characteristic of a wide variety of cellular and subcellular membranes of the $a b / o b$ mouse (Table 2). The Arrhenius break temperatures of DPH polarization are also consistently lower in the membranes of $a b / o b$ mice. These findings suggest that the DPH is partitioning into a different lipid environment in the membranes of $o b / o b$ mice and are indicative of either a change in lipid organization across the membrane bilayer or altered lipid composition. The latter suggestion seems a more likely explanation 
Table 2. Diphenylhexatriene $(D P H)$ fluorescence polarization $\left(P_{37}\right)$ and Arrhenius break temperature of DPH polarization in membranes from lean and obese mice and rats

(Values represent means with their standard errors for at least three observations. Where no standard error is given, value represents mean of two Arrhenius plots. Values are from Hyslop et al. (1982), Hyslop (1981) or D. A. York, unpublished results)

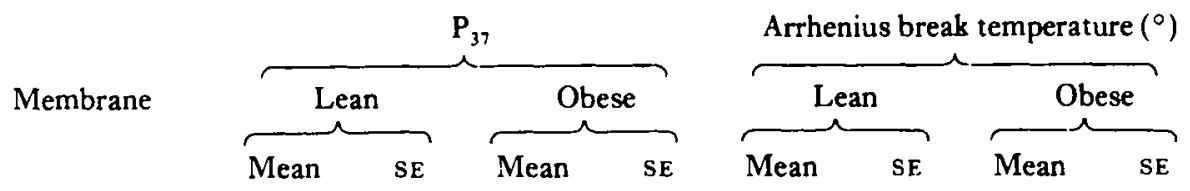

Animal: Lean or obese $(o b / o b)$ mouse

\begin{tabular}{|c|c|c|c|c|c|c|c|c|}
\hline Adipocyte plasma & 0.249 & 0.001 & 0.224 & 0.003 & $25 \cdot 1$ & 0.3 & 17.6 & 0.7 \\
\hline Hepatic plasma & 0.205 & 0.001 & 0.187 & 0.001 & $21 \cdot 2$ & I 3 & 15.8 & I. 2 \\
\hline Salivary gland & & & & & & & & \\
\hline plasma & 0.200 & & 0.185 & & $20 \cdot 3$ & & 177 & \\
\hline Pancreatic plasma & 0.167 & & 0.152 & & & & & \\
\hline Synaptosomal & $0.24 \mathrm{I}$ & & 0.222 & & $23 \cdot 3$ & & $18 \cdot 6$ & \\
\hline Inner mitochondrial: & & & & & & & & \\
\hline Hepatic & 0.197 & & 0.178 & & I9. 8 & & $15 \cdot 4$ & \\
\hline Brown adipose & $0.17^{8}$ & & $0.15^{2}$ & & & & & \\
\hline Hepatic microsomes ${ }^{\bullet}$ & 0.245 & 0.002 & 0.221 & 0.003 & $9 \cdot 5$ & 0.3 & 6.5 & 0.2 \\
\hline Muscle sarcolemmal & 0.237 & & 0.206 & & & & & \\
\hline Erythrocyte & 0.286 & & 0.299 & & $26 \cdot 0$ & & $28 \cdot 2$ & \\
\hline
\end{tabular}

Animal: Lean or obese $(f a / f a)$ Zucker rat

$\begin{array}{lllll}\text { Adipocyte plasma } & 0.223 & 0.208 & 23.7 & 13.5 \\ \text { Synaptosomal } & 0.251 & 0.237 & 25.8 & 19.3\end{array}$

-Total phospholipid extract from these membranes.

since the total phospholipid extract of $o b / o b$ membranes when sonicated into vesicles also shows a reduction in DPH polarization in comparison with phospholipids from lean-mouse membranes (French et al. 1983). The erythrocyte membrane of $o b / a b$ mice is exceptional in that DPH polarization value is increased in comparison with that of lean mice. This is thought to result from an increased equilibration of cholesterol into the membranes from the hypercholesterolaemic serum. Rouer et al. ( 1980 ), in their studies of the microsomal enzyme ethoxycoumarin-o-ethyl transferase ( $E C$ 2.2.1.99), were unable to show any difference in DPH polarization at $37^{\circ}$ although the Arrhenius break temperatures for DPH polarization and enzyme activities were reduced in the $o b / o b$ mice. The apparently normal membrane fluidity in $o b / o b$ mice at $37^{\circ}$ may be an artefact since these workers failed to separate microsomal membranes from the glycogen granules which would greatly enhance light scattering.

DPH polarization in phospholipid vesicles prepared after extraction and separation of membrane phospholipids has been used to identify major differences in phospholipid composition between lean and obese mice. In adipocyte plasma 


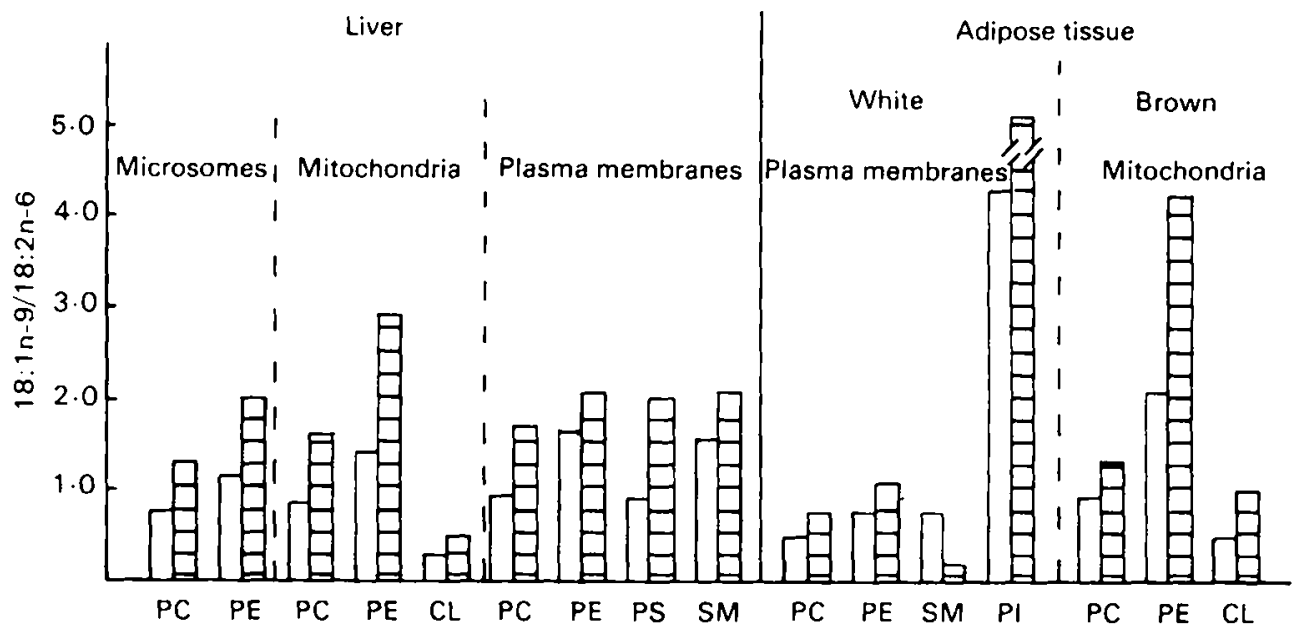

Fig. I. Ratio, oleic ( $18: 1 n-9) /$ linoleic ( $18: 2 n-6)$ acids in phospholipids of tissue and organelle membranes of lean (ㄷ) and obese $o b / a b$ (目) mice. PC, phosphatidylcholines; PE, phosphatidylethanolamines; CL, cardiolipins; PS, phosphatidylserines; SM, sphingomyelins; PI, phosphatidylinositols ( $18: 9$ ).

membranes of $a b / o b$ mice the major change appears to be a large increase in the fluidity of phosphatidylethanolamine (York et al. 1982) which, by derivitization experiments with trinitrobenzene sulphonic acid, has been shown to be located in the inner half of the bilayer (P. S. Hyslop and D. A. York, unpublished results). In contrast, in hepatocyte plasma membranes, the major change appears to be in the sphingomyelin component (York et al. 1982; French et al. 1983) which is normally located in the outer half of membrane phospholipid bilayers (Op den Kamp, 1979). Thus it is likely that fluidity changes in the membranes of $a b / o b$ mice will not be distributed symmetrically across the lipid bilayer and will show both tissue and organelle specificity. It should also be remembered that specific phospholipid changes may result in a redistribution of cholesterol within the bilayer (Hyslop, I $98 \mathrm{I}$ ).

Similar increases in membrane fluidity, as indicated by lower DPH polarization and lower Arrhenius break temperatures, have also been observed in adipocyte plasma membranes and synaptosomal membranes of Zucker obese $f a / f a$ rats (Table 2).

\section{Membrane lipid composition}

There have been numerous reports of tissue lipid composition in $o b / o b$ mice but relatively few reports specifically on membrane lipids. Varandani \& $\mathrm{Nafz}$ (1976) showed that hepatic microsomes from $o b / o b$ mice contained less phospholipid than those from lean mice and that the proportions of the phospholipids, in particular phosphatidylethanolamine and phosphatidic acid, were altered. A reduction in phospholipid content has also been reported in hepatic plasma membranes of $o b / o b$ mice (French et al. 1983) whereas both phospholipid and cholesterol content and 
the distribution of phospholipid subclasses of adipocyte plasma membranes were all unaltered (York et al. 1982).

Changes in the fatty acyl composition of phospholipids in $a b / o b$ mouse membranes are common although there are great variations between individual phospholipids in the same membrane bilayer, between different membrane fractions within the same tissue and between similar membranes in different tissues (Rouer et al. 1980; Hyslop et al. 1982; York et al. 1982; French et al. 1983). For example, a large increase in the proportion of docosohexaenoic acid $(22: 6 n-3)$ in phosphatidylethanolamine has been reported in adipocyte plasma membranes of $o b / o b$ mice, whereas the content of 22:6 fatty acids in phosphatidylethanolamine of hepatic plasma membranes is normal (York et al. 1982; French et al. 1983). However, the one consistent change which has been observed in the membrane phospholipids of $o b / o b$ mice is an increase in the ratio, oleic ( $18: 1 n-9) /$ linoleic $(18: 2 n-6)$ acids, as illustrated in Fig. $r$. This may result, in part at least, from an increased desaturation of linoleic acid $(18: 2 n-6)$ to more unsaturated fatty acids since the activities of both $\Delta 6$ - and $\Delta_{5}$-desaturase enzymes are increased in $o b / o b$ mice (S. Hughes and D. A. York, unpublished results). Normalization of hepatic $\Delta 6$-desaturase activity after thyroid hormone treatment was accompanied by correction of the ratio, $18: 1 / 18: 2$ fatty acids in the phospholipids of hepatic plasma and mitochondrial membranes (Fig. 2.).

Similar increases in the $18: 1 / 18: 2$ value of membrane phospholipids have also been observed (P. A. Hyslop and D. A. York, unpublished results) in hepatic microsomes of gold thioglucose-induced obesity and in synaptosomal membranes of the genetically obese rat, suggesting that these changes may be secondary to the development of obesity.

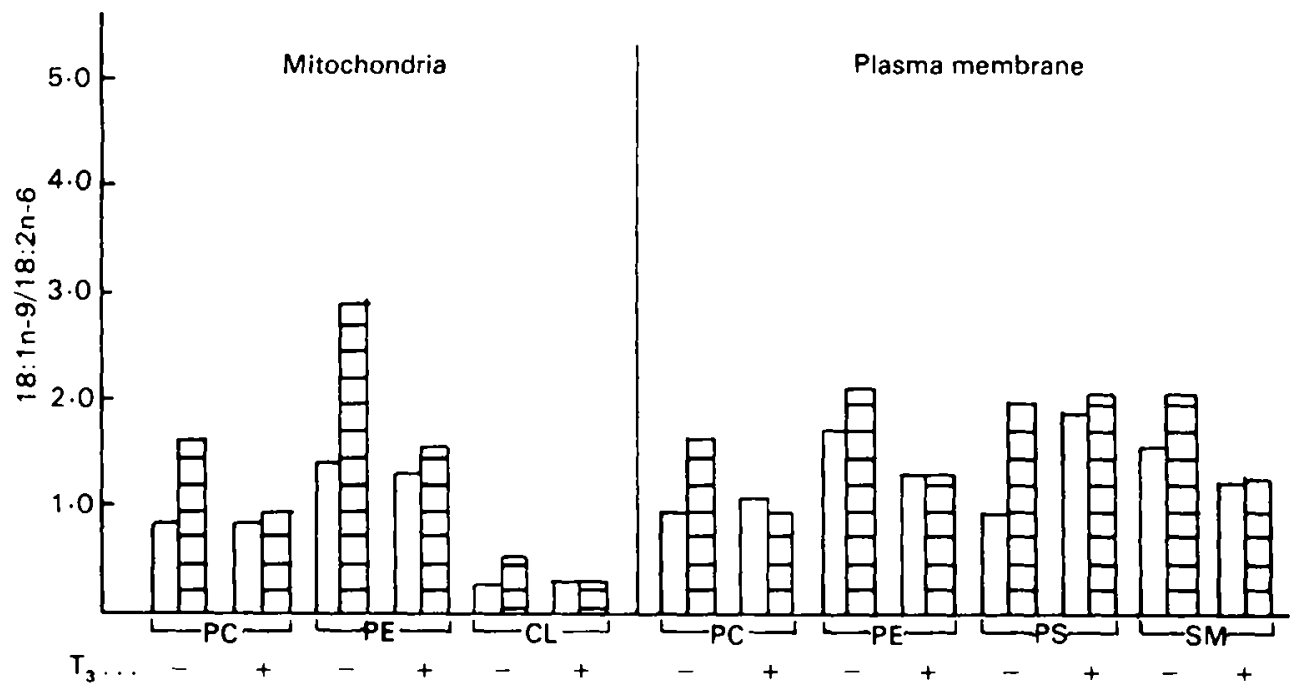

Fig. 2. Effect of triiodothyronine $\left(T_{3}\right)$ on the ratio, oleic (18:1n-9)/linoleic (18:2n-6) acids in liver membrane phospholipids of lean $(\square)$ and obese $o b / o b(\theta)$ mice. $T$, was given at a dose of $50 \mu \mathrm{g} / \mathrm{kg}$ per d. PC, phosphatidylcholines; PE, phosphatidylethanolamines; CL, cardiolipins; PS, phosphatidylserines; SM, sphingomyelins. 
Table 3. Arrhenius break temperatures of $5^{\prime}$-nucleotidase (EC 3.1.3.5) and diphenylhexatriene (DPH) fluorescence polarization, and sphingomyelin acyl composition in hepatic plasma membranes of lean and obese (ob/ob) mice

(Values for $18: 1 / 18: 2$ represent means of two measurements of plasma membranes pooled from five animals in each group)

Arrhenius break temperatures $\left({ }^{\circ}\right)$ :

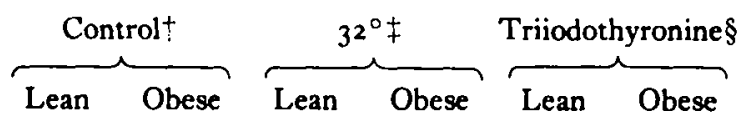

DPH polarization:

Plasma membrane

Sphingomyelin vesicles

$5^{\prime}$-Nucleotidase activity

Sphingomyelin $18: 1 / 18: 2$

$\begin{array}{cccccc}21 \cdot 2 & 15 \cdot 8 \cdots & 15 \cdot 0 & 21 \cdot 3 \cdots & 21 \cdot 1 & 21 \cdot 9 \\ 26 \cdot 0 & 30 \cdot 6 \cdots & 30 \cdot 7 & 23 \cdot 9 \cdots & 23 \cdot 7 & 25 \cdot 6 \cdots \\ 23 \cdot 2 & 32 \cdot 1 \bullet & 29 \cdot 4 & 19 \cdot 2 \cdots & 17 \cdot 7 & 19 \cdot 4 \cdots \\ 1 \cdot 57 & 2 \cdot 11 & 4 \cdot 73 & 1 \cdot 27 & 1 \cdot 23 & 1 \cdot 30\end{array}$

Significantly different from lean value: $\bullet \bullet P<0.01$.

tHoused at $24-25^{\circ}$.

$\ddagger$ Housed at $32^{\circ}$ for $7 \mathrm{~d}$.

$\S 50 \mu \mathrm{g} / \mathrm{kg}$ per $\mathrm{d}$ for $6 \mathrm{~d}$.

It is not clear at which stage of development of the $o b / o b$ mouse the changes in membrane lipid composition or organization, or both, appear. The changes in $\left[\mathrm{Na}^{+}\right.$ $+\mathrm{K}^{+}$]ATPase activity are not apparent either before weaning (Lin et al. 1979a; Hughes \& York, 1983 ) or in a cultured preadipocyte line derived from obese mice (Forest et al. 1982). However, DPH polarization values and 5'-nucleotidase (EC 3.I.3.5) activity of hepatic plasma membranes are already altered immediately before weaning (R. R. French and D. A. York, unpublished results). Such preliminary results suggest that the membrane changes may develop over a period of time around weaning.

\section{Membrane composition and 5'-nucleotidase activity}

An understanding of the precise relation of the changes in membrane composition to the alterations in membrane function, examples of which are shown in Table I, awaits further research. However, the increase in $5^{\prime}$-nucleotidase activity in hepatic plasma membranes of $o b / o b$ mice may result from changes in sphingomyelin composition (French et al. 1983). $5^{\prime}$-Nucleotidase is purified as a sphingomyelin complex (Widnell, 1974; Merisko et al. 1981). The Arrhenius break temperature of hepatic plasma membrane 5 '-nucleotidase was increased in $o b / o b$ mice while the break temperature for DPH polarization in the same membranes was reduced indicating that the enzyme and probe were monitoring different lipid environments. Further studies on animals housed at $34^{\circ}$ or treated with triiodothyronine showed a close correlation between the Arrhenius break temperatures for $5^{\prime}$-nucleotidase and DPH polarization in purified sphingomyelin vesicles (Table 3 and Fig. 3; French et al. 1983). Alterations of the ratio, $(18: 1 n-9 / 18: 2 n-6)$ in sphingomyelin were associated with parallel changes in 


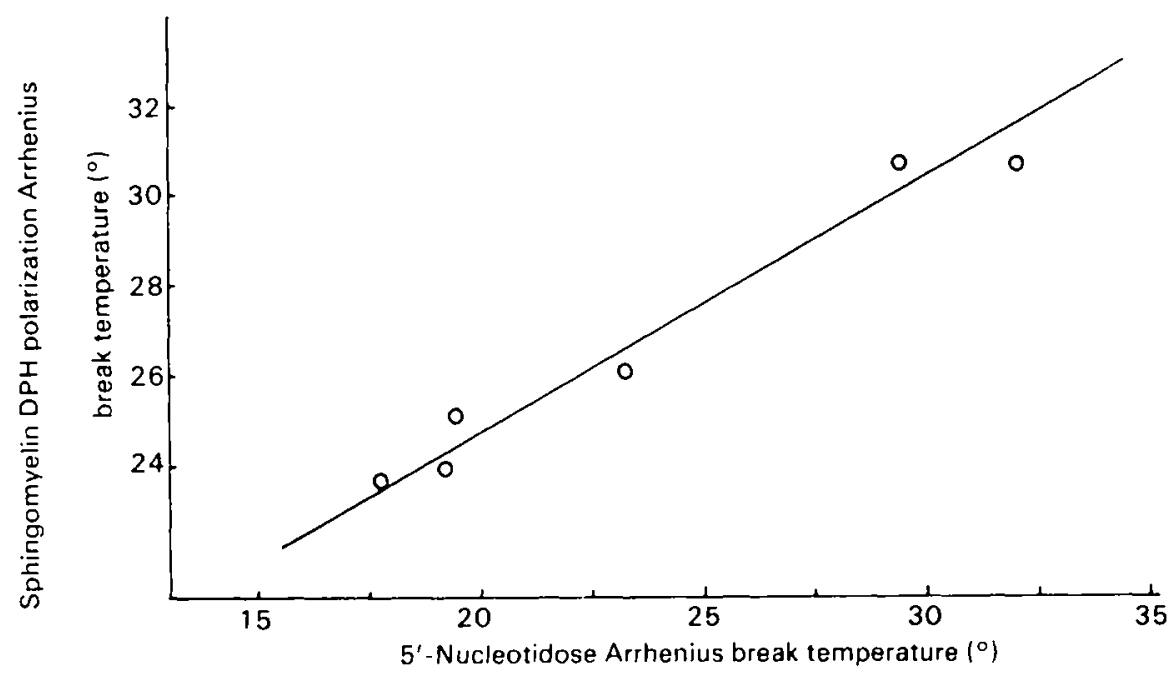

Fig. 3. Relation of Arrhenius break temperature of hepatic plasma membrane 5 '-nucleotidase (EC 3.1.3.5) to Arrhenius break temperature of diphenylhexatriene (DPH) polarization in vesicles prepared from membrane sphingomyelin. Values are taken from Table 3.

Regression equation: $y=1 \cdot 84 x-25 \cdot 6, r 0.97$.

Arrhenius break points of enzyme and activity of DPH polarization. No other phospholipid showed any close association of Arrhenius characteristics.

\section{Membrane changes in other obesities}

Very few investigations have been reported to date on either membrane composition or function in other forms of obesity. $\left[\mathrm{Na}^{+}+\mathrm{K}^{+}\right]$ATPase activity is reduced in the diabetic $d b / d b$ mouse but is unaltered in either gold thioglucose-induced obesity or the genetic obesity of the fatty fa/fa rat (Bray et al. 1978). Hepatic and erythrocyte $\left[\mathrm{Na}^{+}+\mathrm{K}^{+}\right]$ATPase may be increased in human obesity (Bray et al. 1981; Mir et al. 1981) although some reports have found a reduction in enzyme activity in the obese (Deluise et al. 1980; Beutler et al. 1982). Since the majority of obese individuals are hypertriglyceridaemic and hypercholesterolaemic it might be expected that the lipid composition of blood cell membranes might be altered and this could be reflected in changes in cellular function. Studies with the obese mouse have shown that the membrane changes are individual to each tissue or organelle membrane. Thus it is unlikely that a particular change in membrane composition or function will be found universally in all forms of obesity, but rather that the changes may differ according to aetiology, age of onset, diet, etc. Further research is required to investigate the frequency of membrane compositional changes in other forms of obesity and their relevance to the altered metabolic status of obesity. 


\section{REFERENCES}

Assimacopoulos-Jeannet, F., Cantau, B., van der Werve, G., Jard, S. \& Jeanrenaud, B. ( 1084 ). Biochemical fournal 216, 475-480.

Begin-Heick, N. (1981). Canadian Yournal of Biochemistry 59, 816-820.

Beloff-Chain, A., Bogdanovic, S. \& Cawthorne, M. (1979). Fournal of Endocrinology 81, 271-279.

Beloff-Chain, A., Newman, M. E. \& Mansford, K. R. C. (1973). Diabetologia 9, 447-452.

Beutler, E., Sacks, P. \& Kuhl, W. (1982). New England Yournal of Medicine 306, 808-809.

Billingham, N., Beloff-Chain, A. \& Cawthome, M. (1982). Fournal of Endocrinology 94, $125^{-1} 3_{0}$.

Bray, G. A. \& York, D. A. (1979). Physiological Reviews 59, 719-809.

Bray, G. A., York, D. A. \& Yukimura, Y. (1978). Life Sciences 22, $1637-1642$.

Bray, G. A., Krol, J. G. \& Bjorntorp, P. (1981). New England Fournal of Medicine 305, $1264-1268$.

Chang, K., Huang, D. \& Cuatrecasas, P. (1975). Biochemical and Biophysical Research Communications 64, 566-573.

Cuendot, G. S., Loten, E. G., Jeanrenaud, B. \& Renold, A. E. (1976). Fournal of Clinical Investigation 58, 1078-1088.

Czech, M. P. (1980). Diabetes 29, 399-409.

Dehaye, J. P., Winand, J., Poloczek, P. \& Christophe, J. (1979). Diabetologia 16, 399-408.

Deluise, M., Blackburn, G. L. \& Flier, J. S. (1980). New England Yournal of Medicine 303, IOI 7-1022.

Flier, J. S., Usher, J. \& Deluise, M. (1981). Diabetes 30, 975-978.

Forest, C., Panzia, F., Rossi, B., Luzdunski, M. \& Ailhaud, G. (1982). Biochemical and Biophysical Research Communications 107, 422-428.

Fraser, D. R. \& Trayhurn, P. (1984). Biochemical Fournal 214, 263-1 70.

French, R. R. \& York, D. A. (1984). Diabetologia 26, 466-472.

French, R. R., York, D. A., Portman M. \& Isaacs, K. (1983). Comparative Biochemistry and Physiology 76B, 309-319.

Ginsberg, B. H., Brown, T. J., Simon, I. \& Spector, A. A. (1981). Diabetes 30, 773-780.

Gould, R. J., Ginsberg, B. H. \& Spector, A. A. (1979). Endocrine Research Communications 6, 279-290.

Grundleger, M. L., Godbole, V. \& Thenen, S. W. (1980). American Journal of Physiology 239 , $\mathrm{E}_{3} \mathrm{G}_{3}-\mathrm{E}_{37 \mathrm{r}}$.

Hogan, S. \& Himms-Hagen, J. (1980). American fournal of Physiology 239, E30I-E30g.

Houslay, M. (1985). Proceedings of the Nutrition Society 44, $157^{-165 .}$

Houslay, M. D. \& Gordon, L. M. (1983). Current Topics in Membrane and Transport, vol. 18, pp. 180-231 [A. Kleinzeller and B. R. Martin, editors]. New York: Academic Press.

Hughes, S. \& York, D. A. (1983). Hormone and Metabolic Research 15, 335-339.

Hyslop, P. A. ( 1981 ). A study on the role of the molecular organisation of cell membranes in the development of obesity. PhD Thesis, University of Southampton.

Hyslop, P. A. \& York, D. A. ( 1980$)$. Biochemical and Biophysical Research Communications 92, $819-824$.

Hyslop, P. A., York, D. A. \& Corina, D. (1982). International fournal of Obesity 6, 279-289.

Innis, R. M \& Clandinin, M. T. (1981). Biochemical fournal 193, 155-164.

Jeanrenaud, B. (1981). Recent Advances in Obesity Research, vol. 3, pp. 159-1 70 [P. Bjorntorp, M. Cairella and A. Howard, editors]. London: John Libbey.

Jorgensen, P. L. (1982). Biochimica et Biophysica Acta 694, 27-68.

Kahn, C. R., Neville, D. M. \& Roth, J. (1973). Fournal of Biological Chemistry 248, 244-250.

Katyare, S. S. \& Howland, J. L. (1980). Archives of Biochemistry and Biophysics 188, I 5-20.

Kirolovsky, J. \& Schramm, M. ( 1983 ). Fournal of Biological Chemistry 258, $68_{4} \mathrm{I}-6849$.

Lavine, R. L., Voyles, N., Perrino, P. V. \& Recant, L. (1977). American Fournal of Physiology 233, E86-Ego.

Lee, A. (1985). Proceedings of the Nutrition Society 44, 147-1 56.

Le Marchand-Brustel, Y. \& Freychet, P. (1978). Metabolism 27, 1982-1993.

Le Marchand-Brustel, Y., Jeanrenaud, B. \& Freychet, P. (1978). American fournal of Physiology 234, $\mathrm{E}_{348}-\mathrm{E}_{35} 8$. 
Lin, M. H., Romsos, D. R., Akera, T. \& Leveille, G. A. (1978). Biochemical and Biophysical Research Communications 80, 398-404.

Lin, M. H., Romsos, D. R., Akera, T. \& Leveille, G. A. (1979a) Proceedings of the Society for Experimental Biology and Medicine $16 \mathrm{r}, 235^{-2} 3^{8}$.

Lin, M. H., Van der Tuig, J. G., Romsos, D. R., Akera, T. \& Leveille, G. A. (1979b). American Fournal of Physiology 237, $\mathrm{E}_{26} 6_{5}-\mathrm{E}_{27} 2$.

Loh, H. H. \& Law, P. Y. (1980). Annual Review of Pharmacology and Toxicology 20, 201-234.

McMurdine, E. J., Abeywardena, M. Y., Charnock, J. S. \& Gibson, R. A. (1983). Biochimica et Biophysica Acta 760, $\times 3-24$.

Makula, R. A. \& Goekjian, V. (1982). Biochemical and Biophysical Research Communications 108, 647-653.

Meade, C. J. \& Sheena, J. (1979). Animal Models of Obesity, pp. 205-220. [M. F. V. Festing, editor]. London: Macmillan Press.

Merisko, E. M., Ojakian, G. K. \& Widnell, C. C. (1981). Fournal of Biological Chemistry 256, $1983-1993$.

Mir, M. A., Charalambous, B. M., Morgan, K. \& Evans, P. J. (1981). New England fournal of Medicine 305, $1264-1268$.

Op den Kamp, J. (1979). Annual Review of Biochemistry 48, 47-71.

Oshima, K., Shargill, N. S., Chan, T. M. \& Bray, G. A. (1984). American Journal of Physiology 246, Er93-E 197 .

Rouer, E., Dansette, P., Beaune, P. \& Leroux, J-P. (1980). Biochemical and Biophysical Research Communications $95,41-46$.

Sanderman, H. (1978). Biochimica et Biophysica Acta 5 15, 209-237.

Sena, A., Rebel, G., Beith, R., Hubert, P. \& Waksman, A. (1982). Biochimica et Biophysica Acta 710, 290-296.

Smith, A. D., Conroy, D. M., Belin, J. \& Stubbs, C. D. (1985). Proceedings of the Nutrition Society 44, $201-209$.

Soll, A., Kahn, D., Neville, D. \& Roth, J. (1975). Journal of Biological Chemistry 250, 4702-4707.

Stubbs, C. D. \& Smith, A. D. (1984). Biochimica et Biophysica Acta 779, 89-1 37.

Varandani, P. \& Nafz, M. A. (1976). Biochimica et Biophysica Acta 45 I, 382-392.

Vitale, J. \& Broitman, S. (1981). Cancer Reseurch 41, 3706-3710.

Wahle, K. W. J. (1983). Proceedings of the Nutrition Society 42, 273-287.

Widnell, C. C. (1974). Methods of Enzymology, vol. 32, pp. 368-374 [S. Fleischer and L. Packer, editors]. New York: Academic Press.

York, D. A., Bray, G. A. \& Yukimura, Y. (1978). Proceedings of the National Academy of Sciences, USA 75, 477-48r.

York, D. A., Hyslop, P. A. \& French, R. R. (1982). Biochemical and Biophysical Research Communications 106, $1478-1483$. 